\title{
POLYCYCLIC AROMATIC HYDROCARBONS IN THE AIR NEAR GAS FIELD MOLVE
}

\author{
Ranka GODEC, Anica ŠIŠOVIĆ, Ivan BEŠLIĆ, and Vladimira VAĐIĆ \\ Institute for Medical Research and Occupation Health, Zagreb, Croatia \\ Received in April 2008 \\ Accepted in July 2008
}

\begin{abstract}
Small-volume air samples $\left(\sim 7 \mathrm{~m}^{3}\right.$ per $24 \mathrm{~h}$ ) of airborne $\mathrm{PM}_{10}$ particle fraction were collected on quartz fibre filters at two measuring sites in the vicinity of the gas field Molve in April and July 2006. It took five to seven days for each sample to collect and one month to collect five to seven samples. Mass concentrations of $\mathrm{PM}_{10}$ fractions were determined by gravimetry while PAHs were analysed using a HPLC with a fluorescent detector. The analysis included fluoranthene (Flu), pyrene (Pyr), benzo(a)anthracene (BaA), chrysene (Cry), benzo(b)fluoranthene $(\mathrm{BbF})$, benzo(k)fluoranthene $(\mathrm{BkF})$, benzo(a)pyrene $(\mathrm{BaP})$, benzo(ghi)perylene (BghiP) and indene(1,2,3-cd)pyrene (Ind). Average concentrations of all PAHs in April at site A were slightly higher than at site $B$ while in July they were lower and similar on both sites. Average $\mathrm{BaP}$ concentration measured at site A in April was $0.156 \mathrm{ng} \mathrm{m}^{-3}$ and at site B $0.129 \mathrm{ng} \mathrm{m}^{-3}$, while July BaP averages were $0.022 \mathrm{ng} \mathrm{m}^{-3}$ at both sites. In both months, the mass concentration of $\mathrm{BaP}$ was lower than the limit value $\left(1 \mathrm{ng} \mathrm{m}^{-3}\right)$ and well below the tolerant value $\left(2 \mathrm{ng} \mathrm{m}^{-3}\right)$ set by a Croatian regulation of 2005 . This suggests that the air near gas field Molve was of acceptable quality in respect to $\mathrm{BaP}$ at the time of the measurement.
\end{abstract}

KEY WORDS: Benzo(a)pyrene, limit value, mass concentration, $P M_{10}$ particle fraction, tolerant value

Polycyclic aromatic hydrocarbons (PAHs) are a group of organic compounds with two or more aromatic rings. PAHs are a result of incomplete combustion of fossil fuels and other organic materials. Their sources include natural processes (forest fires and volcanic eruptions) and anthropogenic emissions (motor vehicles, industrial processes, refining, domestic heating, and tobacco smoke) (1-3). PAH concentration levels in the atmosphere depend on heating, traffic density, and the type of industrial emissions. They tend to vary with season and meteorological conditions. There are several hundred PAHs; the best known is benzo(a)pyrene (BaP), which is commonly used as an indicator of PAHs in the air. It has been observed that PAHs might add to the carcinogenicity of particulate matter (4). Experiments have shown that $\mathrm{BaP}$ is mutagenic and carcinogenic.
This has also been demonstrated for some other PAHs (5). It is necessary to reduce atmospheric concentrations of carcinogenic substances as much as possible, and one way to do it gradually is to set recommended and limit values of air quality. The 2004 Air protection Act (6) defines limit value (LV) and tolerant value (TV), and sets three categories of air

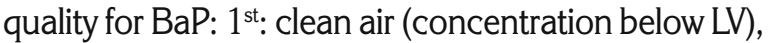
$2^{\text {nd: }}$ moderately polluted air (concentration over $\mathrm{LV}$ and below TV), and $3^{\text {rd }}$ category: polluted air (concentration over TV).This paper presents variations in $\mathrm{PAH}$ mass concentrations in the $\mathrm{PM}_{10}$ particle fraction collected at two measuring sites in the vicinity of the gas filed Molve in April and July 2006. The purpose was to determine whether and to what extent INA d.d.- CPS Molve plant pollutes ambient air with PAHs. 


\section{MATERIALS AND METHODS}

\section{Collection of samples}

Samples of airborne $\mathrm{PM}_{10}$ fractions (particles with aerodynamic diameter smaller than $10 \mu \mathrm{m}$ ) were collected with small-volume samplers. Samples were collected on quartz fiber filters, $47 \mathrm{~mm}$ in diameter, with MiniVol portable air sampler (Airmetrics, USA) at an air flow of $0.300 \mathrm{~m}^{3} \mathrm{~h}^{-1}$. It took five to seven days for each sample to collect and one month to collect five to seven samples. Samples were collected at two measuring sites MOL-9 (A) and MOL-10 (B) at the same time in April and July 2006. Site A is situated about $500 \mathrm{~m}$ to the northeast of the INA d.d.- CPS Molve plant, while site B is located about $1000 \mathrm{~m}$ to the south. Samples of $\mathrm{PM}_{10}$ fractions were wrapped in aluminium foil and frozen to $-18{ }^{\circ} \mathrm{C}$ till analysis. Mass concentrations of $\mathrm{PM}_{10}$ fractions were determined using the gravimetric method.

\section{Sample analysis}

Preparation samples for PAH analysis consisted of several steps. Samples were first extracted in an ultrasonic bath with cyclohexane for one hour. After extraction, samples were separated from undissolved parts by centrifugation to prevent little parts of filters get into the HPLC column. The refined extract was evaporated to dryness under a stream of nitrogen and re-dissolved in acetonitrile (7). PAHs were analysed using a VARIAN ProStar HPLC and fluorescence detector with changeable excitation and emission wavelength.

PAHs were separated on a Varian stainless steel Chrompoe CP-ECO Spher 4 PAH column. The mobile phase was a mixture of acetonitrile and water, and the flow rate was $0.4 \mathrm{~mL} \mathrm{~min}^{-1}$. For calibration we used a commercial PAH standard (Supelco EPA 610 PAHs mix).

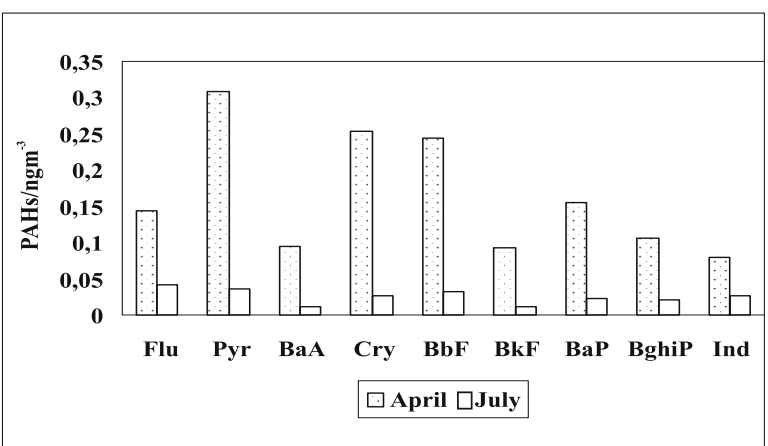

Figure 1 Average mass concentrations of PAHs at site A in April and July 2006
Samples were analysed for the following PAHs: fluoranthene (Flu), pyrene (Pyr), benzo(a)anthracene $(\mathrm{BaA})$, chrysene (Cry), benzo(b)fluoranthene $(\mathrm{BbF})$, benzo(k)fluoranthene $(\mathrm{BkF})$, benzo(a)pyrene $(\mathrm{BaP})$, benzo(ghi)perylene (BghiP), and indeno(1,2,3cd)pyrene (Ind).

\section{RESULTS AND DISCUSSION}

Table 1 shows statistical parameters of PAH mass concentrations measured on sites A and B in April 2006. At both sites the highest average value was recorded for Pyr and the lowest for BkF. Average mass concentration of BghiP at site A was slightly higher than at site B. Similar was noted for the average mass concentration of $\mathrm{BaP}$. In April average mass concentrations of all PAHs at site $A$ were slightly higher than at site $B$, except for Flu and Ind. The measuring site A is significantly closer to INA d.d.- CPS Molve plant, so there is a possibility of a relatively small influence of flue gases from INA d.d.- CPS Molve plant at site $\mathrm{A}$.

Table 2 shows statistical parameters of PAH mass concentrations measured in July 2006. Average mass concentrations at both sites were very low, near the detection limit. At site A, Flu had the highest average value $\left(0.042 \mathrm{ng} \mathrm{m}^{-3}\right)$ and $B a A$ had the lowest $\left(0.011 \mathrm{ng} \mathrm{m}^{-3}\right)$. At site $\mathrm{B}, \mathrm{BbF}$ had the highest average value $\left(0.059 \mathrm{ng} \mathrm{m}^{-3}\right)$ and again BaA had the lowest $\left(0.008 \mathrm{ng} \mathrm{m}^{-3}\right)$. Average mass concentrations of all PAHs at site B were slightly higher than at site A, except for Flu and BaA. Average mass concentration of $\mathrm{BaP}$ was the same at both sites $\left(0.022 \mathrm{ng} \mathrm{m}^{-3}\right)$. We believe that in summer days measurements at the site A may have been influenced by flue gases from INA d.d.- CPS Molve.

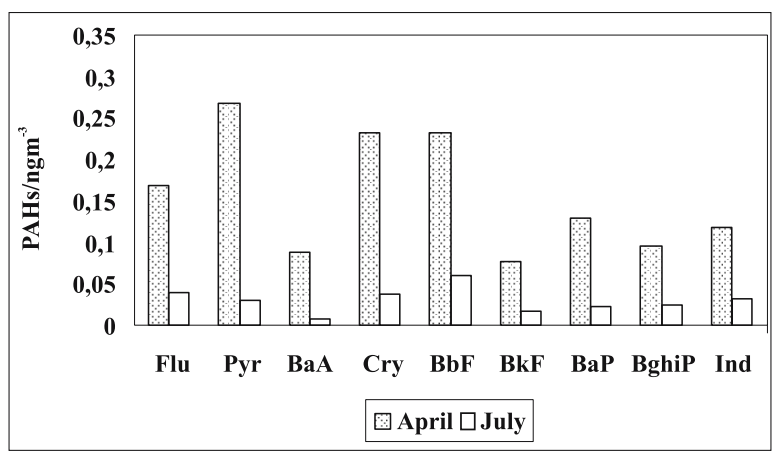

Figure 2 Average mass concentrations of PAHs at site B in April and July 2006 
Table 1 Statistical parameters of PAH mass concentrations $\left(\mathrm{ng} \mathrm{m}^{-3}\right.$ ) measured in April 2006

\begin{tabular}{|c|c|c|c|c|c|c|c|c|c|c|}
\hline \multirow{2}{*}{$\begin{array}{l}\text { Measuring } \\
\text { site }\end{array}$} & \multirow{2}{*}{$\begin{array}{l}\text { Statistical } \\
\text { parameter }\end{array}$} & \multicolumn{9}{|c|}{ PAHs } \\
\hline & & Flu & Pyr & $\mathrm{BaA}$ & Cry & $\mathrm{BbF}$ & $\mathrm{BkF}$ & $\mathrm{BaP}$ & BghiP & Ind \\
\hline \multirow{5}{*}{ A } & $\mathrm{N}$ & 7 & 7 & 7 & 7 & 7 & 7 & 7 & 7 & 7 \\
\hline & $C_{\min }$ & 0.067 & 0.062 & 0.015 & 0.094 & 0.055 & 0.026 & 0.040 & 0.041 & 0.026 \\
\hline & $C_{\max }$ & 0.252 & 0.712 & 0.254 & 0.720 & 0.603 & 0.248 & 0.352 & 0.212 & 0.182 \\
\hline & $C$ & 0.114 & 0.308 & 0.095 & 0.253 & 0.245 & 0.093 & 0.156 & 0.106 & 0.079 \\
\hline & STD & 0.066 & 0.198 & 0.072 & 0.199 & 0.162 & 0.068 & 0.093 & 0.050 & 0.046 \\
\hline \multirow{5}{*}{ B } & $\mathrm{N}$ & 7 & 7 & 7 & 7 & 7 & 7 & 7 & 7 & 7 \\
\hline & $\mathrm{C}_{\min }$ & 0.078 & 0.084 & 0.023 & 0.075 & 0.060 & 0.026 & 0.049 & 0.031 & 0.049 \\
\hline & $C_{\text {max }}$ & 0.409 & 0.716 & 0.301 & 0.725 & 0.580 & 0.211 & 0.331 & 0.269 & 0.319 \\
\hline & $C$ & 0.168 & 0.268 & 0.088 & 0.232 & 0.232 & 0.076 & 0.129 & 0.096 & 0.118 \\
\hline & STD & 0.107 & 0.203 & 0.090 & 0.208 & 0.157 & 0.058 & 0.091 & 0.077 & 0.083 \\
\hline
\end{tabular}

$N$ - number of samples

$\mathrm{C}$ - average value

$\mathrm{C}_{\min }$ - minimum value

STD - standard deviation

$\mathrm{C}_{\max }$ - maximum value

Table 2 Statistical parameters of PAH mass concentrations ( $\mathrm{ng} \mathrm{m}^{-3}$ ) measured in July 2006

\begin{tabular}{|c|c|c|c|c|c|c|c|c|c|c|}
\hline \multirow{2}{*}{$\begin{array}{l}\text { Measuring } \\
\text { site }\end{array}$} & \multirow{2}{*}{$\begin{array}{l}\text { Statistical } \\
\text { parameters }\end{array}$} & \multicolumn{9}{|c|}{ PAHs } \\
\hline & & Flu & Pyr & $\mathrm{BaA}$ & Cry & $\mathrm{BbF}$ & $\mathrm{BkF}$ & $\mathrm{BaP}$ & BghiP & Ind \\
\hline \multirow{5}{*}{ A } & $N$ & 5 & 5 & 5 & 5 & 5 & 5 & 5 & 5 & 5 \\
\hline & $C_{\text {min }}$ & 0.025 & 0.025 & 0.006 & 0.017 & 0.014 & 0.009 & 0.014 & 0.017 & 0.015 \\
\hline & $C_{\text {max }}$ & 0.055 & 0.066 & 0.025 & 0.048 & 0.047 & 0.018 & 0.031 & 0.026 & 0.049 \\
\hline & $C$ & 0.042 & 0.036 & 0.011 & 0.026 & 0.033 & 0.012 & 0.022 & 0.020 & 0.027 \\
\hline & STD & 0.011 & 0.015 & 0.007 & 0.011 & 0.011 & 0.004 & 0.006 & 0.004 & 0.012 \\
\hline \multirow{5}{*}{ B } & $\mathrm{N}$ & 5 & 5 & 5 & 5 & 5 & 5 & 5 & 5 & 5 \\
\hline & $C_{\min }$ & 0.014 & 0.025 & 0.001 & 0.021 & 0.028 & 0.008 & 0.010 & 0.015 & 0.019 \\
\hline & $\mathrm{C}_{\max }$ & 0.072 & 0.066 & 0.014 & 0.058 & 0.100 & 0.024 & 0.033 & 0.033 & 0.041 \\
\hline & $C$ & 0.039 & 0.036 & 0.008 & 0.037 & 0.059 & 0.016 & 0.022 & 0.024 & 0.032 \\
\hline & STD & 0.020 & 0.016 & 0.005 & 0.015 & 0.024 & 0.005 & 0.008 & 0.006 & 0.008 \\
\hline
\end{tabular}

$N$ - number of samples

$\mathrm{C}$ - average value

$\mathrm{C}_{\text {min }}$ - minimum value

STD - standard deviation

$\mathrm{C}_{\max }$ - maximum value

The tables show weekly minimum and maximum mass concentrations; daily variations and ranges could be even higher because there are greater differences between daily minimums and maximums.

Figure 1 shows average mass concentrations of PAHs at site A in April and July 2006. All PAH concentrations at sampling site $A$ were higher in April than in July. The greatest difference was observed for
Pyr and the lowest for Ind, because Ind is more stable than Pyr $(8,9)$. At site A, average mass concentrations of $\mathrm{BaP}$ and $\mathrm{BkF}$ were similar in April, and the same is true for Cry and Ind in July.

Figure 2 shows average mass concentrations of PAHs at site B in April and July 2006. There too the concentrations of all measured PAHs were higher in April than in July. April averages of Cry and BbF were 
Table 3 Statistical parameters of $P M_{10}$ fraction mass concentrations $\left(\mu \mathrm{g} \mathrm{m}^{-3}\right)$ measured at sites A and B in April and July 2006

\begin{tabular}{lcccc}
\hline \multirow{2}{*}{ Statistical parameters } & \multicolumn{3}{c}{ Measuring site } \\
& & A & B \\
\cline { 2 - 5 } & April & July & April & July \\
\hline N & 7 & 5 & 7 & 5 \\
Cmin & 10.6 & 23.6 & 16.6 & 15.6 \\
Cmax & 33.1 & 44.0 & 28.1 & 39.4 \\
C & 19.4 & 33.1 & 21.2 & 27.1 \\
STD & 6.4 & 7.0 & 3.5 & 8.5 \\
\hline
\end{tabular}

$N$ - number of samples

$\mathrm{C}$ - average value

$\mathrm{C}_{\min }$ - minimum value

STD - standard deviation

$\mathrm{C}_{\max }$ - maximum value

similar and July BghiP and BaP averages were very low and also similar.

A comparison shows that April PAH concentrations were 10 times higher than in July. The highest difference between April and July was observed for Pyr at both measuring sites while differences in Cry, Bbf, Flu, and $\mathrm{BaP}$ were somewhat lower. The main reason may be that at higher temperatures these compounds react more readily $(9,10)$.

According to Croatian legislation of 1995 (11) and 1996 (12), BaP RV was $0.2 \mathrm{ng} \mathrm{m}^{-3}$, and LV was $2 \mathrm{ng} \mathrm{m}^{-3}$. However limited to two months only, our measurement showed that $\mathrm{BaP}$ mass concentration kept well under RV, and that the air near gas field Molve was of the first quality in this respect.

The 2004 Air Protection Act (6) and the 2005 Regulation on Limit Values of Pollutants in Ambient Air (13), has lowered the BaP LV to $1 \mathrm{ng} \mathrm{m}^{-3}$ and has introduced a tolerable value (TV) of $2 \mathrm{ng} \mathrm{m}^{-3}$. Even with these changes, the air quality near gas field Molve has remained of the first category.

Table 3 shows statistical parameters of mass concentrations of the $\mathrm{PM}_{10}$ fraction measured at sites $A$ and B in April and July 2006. A comparison shows that $\mathrm{PM}_{10}$ mass concentrations were slightly higher at both sites in July than in April. The reason may be more windy days when low particles from agricultural fields were flying near measuring site.

\section{CONCLUSION}

Average mass concentration of all PAHs on both measuring sites in both months were relatively low. In April they were slightly higher at site A than at site
B, while in July they were lower and similar on both sites. Average mass concentrations of $\mathrm{PM}_{10}$ fraction in July were higher than in April. Although INA d.d.- CPS Molve plant pollutes air with some other pollutants, our results suggest that it does not significantly contribute to air PAH concentrations. Although sampling was conducted in two months only, the mass concentration of $\mathrm{BaP}$ was well below the limit value ( $1 \mathrm{ng} \mathrm{m}^{-3}$, according to the 2005 regulation). This suggests that the air near gas field Molve was of acceptable quality in respect to $\mathrm{BaP}$ at the time of the measurement.

\section{REFERENCES}

1. Nikolau K, Masclet P, Mouvier G. Sources and chemical reactivity of polynuclear aromatic hydrocarbons in the atmosphere - a critical review. Sci Total Environ 1984;32:103-32.

2. Maliszewska-Kordybach B. Sources, concentrations, fate and effects of polycyclic aromatic hydrocarbons (PAHs) in the environment. Part A: PAHs in air. Polish J Environ Stud 1999;8:131-6.

3. Boonyatumanond R, Murakami M, Wattayakorn G, Togo A, Takada H. Sources of polycyclic aromatic hydrocarbons (PAHs) in street dust in a tropical Asian mega-city, Bangkok, Thailand. Sci Total Environ 2007;384:420-32.

4. World Health Organization (WHO). Air Quality Guidelines [displayed 26 July 2007]. Available at http://www.euro.who.int/document/aiq/5_9pah.pdf.

5. International Agency for Research on Cancer (IARC). Polycyclic aromatic hydrocarbons [displayed 26 July 2007]. Available at http://monographs.iarc.fr/ENG/ Meetings/92-pahs.pdf. 
6. Zakon o zaštiti zraka [Air Protection Act, in Croatian]. NN 2004/178.

7. Šišović A, Fugaš $M$. Comparative evaluation of procedures for the determination of PAH in low-volume samples. Environ Monit Assess 1991;18:235-41.

8. Westerholm R, Stenberg U, Alsberg T. Some aspects of the distribution of polycyclic aromatic hydrocarbons (PAH) between particles and gas phase from diluted gasoline exhausts generated with the use of a dilution measuring in ambient air. Atmos Environ 1988;22:1005-10.

9. Yamasaki H, Kuwata K, Miyamoto H. Effects of ambient temperature on aspects of airborne polycyclic aromatic hydrocarbons. Environ Sci Technol 1982;16:189-94.

10. Butler JD, Crossley P. Reactivity of polycyclic aromatic hydrocarbons adsorbed on soot particles. Atmos Environ 1981;15:91-4.

11. Zakon o zaštiti zraka [Air Protection Act, in Croatian]. NN 1995/48.

12. Uredba o preporučenim i graničnim vrijednostima kakvoće zraka [Regulation on recommended and limit values on air protection, in Croatian]. NN 1996/101.

13. Uredba o graničnim vrijednostima onečišćujućih tvari u zraku [Regulation on limit values of pollutants in ambient air, in Croatian]. NN 2005/133. 


\section{Sažetak}

\section{POLICIKLIČKI AROMATSKI UGLJIKOVODICI U ZRAKU OKOLICE PLINSKOG POLJA MOLVE}

Uzorci $\mathrm{PM}_{10}$ frakcije lebdećih čestica skupljani su prosisavanjem malog volumena zraka $\left(\sim 7 \mathrm{~m}^{3}\right.$ za 24 h) kroz filtre od kvarcnih vlakana. Svaki je uzorak skupljan tijekom pet do sedam dana na dva mjerna mjesta u okolici plinskog polja Molve. Uzorkovanje je provedeno tijekom travnja i srpnja 2006. godine. Masene koncentracije $\mathrm{PM}_{10}$ frakcije određene su gravimetrijski, dok je analiza policikličkih aromatskih ugljikovodika (PAU) rađena tekućinskom kromatografijom visoke djelotvornosti (HPLC) s fluorescentnim detektorom. Mjereni su sljedeći PAU: fluoranten, piren, benzo(a)antracen, krizen, benzo(b)fluoranten, benzo(k)fluoranten, benzo(a)piren, benzo(ghi)perilen i indeno(1,2,3-cd)piren. Srednje vrijednosti masenih koncentracija svih PAU u travnju na mjernome mjestu A bile su neznatno više od onih na mjernome mjestu B, dok su u srpnju na oba mjerna mjesta bile vrlo slične. Srednja vrijednost koncentracije BaP izmjerenog u travnju na mjernome mjestu A bila je viša od vrijednosti izmjerene na mjernome mjestu B. U srpnju su srednje vrijednosti bile znatno niže i na oba mjerna mjesta iznosile su $0.022 \mathrm{ng} \mathrm{m}^{-3}$. Iz rezultata dobivenih mjerenjem vidljivo je da je koncentracija benzo(a)pirena bila znatno niža od granične vrijednosti (1 $\mathrm{ng} \mathrm{m}^{-3}$ ) i tolerantne vrijednosti (1 $\mathrm{ng} \mathrm{m}^{-3}$, Uredba iz 2005.), pa možemo zaključiti da je zrak u okolici plinskog polja Molve tijekom istraživanog razdoblja bio prve kategorije kakvoće.

KLJUČNE RIJEČI: benzo(a)piren, granična urijednost, masena koncentracija, $P M_{10}$ frakcija lebdećih čestica, tolerantna urijednost

\section{CORRESPONDING AUTHOR:}

Ranka Godec, dipl. ing. kemije Institute for Medical Research and Occupation Health Environmental Hygiene Unit Ksaverska c. 2, 10000 Zagreb E-mail: rgodec@imi.hr 